\title{
Wearables and the internet of things: considerations for the life and health insurance industry - CORRIGENDUM
}

A. Spender, C. Bullen, L. Altmann-Richer, J. Cripps, R. Duffy, C. Falkous, M. Farrell, T. Horn, J. Wigzell and W. Yeap

https://doi.org/10.1017/S1357321719000072 Published online by Cambridge University Press, 18 July 2019

Keywords: Wearables; Internet of Things; Technology; Continuous Underwriting; Innovation; Corrigendum

This article (Spender et al., 2019) contains an error. The COVALENCE platform referred to in section 5.3 is proprietary to Big Cloud Analytics, not Intel. In 2017, Big Cloud Analytics rebranded to become EVŌ (http://evo.science).

\section{Reference}

Spender A, Bullen C, Altmann-Richer L, Cripps J, Duffy R, Falkous C, Farrell M, Horn T, Wigzell J, and Yeap W. (2019) Wearables and the internet of things: considerations for the life and health insurance industry. British Actuarial Journal, 24, e22.

Cite this article: Spender A, Bullen C, Altmann-Richer L, Cripps J, Duffy R, Falkous C, Farrell M, Horn T, Wigzell J, and Yeap W. Wearables and the internet of things: considerations for the life and health insurance industry - CORRIGENDUM. British Actuarial Journal. https://doi.org/10.1017/S1357321719000187

\footnotetext{
(C) Institute and Faculty of Actuaries 2019. This is an Open Access article, distributed under the terms of the Creative Commons Attribution licence (http://creativecommons.org/licenses/by/4.0/), which permits unrestricted re-use, distribution, and reproduction in any medium, provided the original work is properly cited.
} 